\title{
HUBUNGAN TINGKAT STRES TERHADAP PENINGKATAN KADAR GULA DARAH PADA PASIEN DM TIPE II DI RSU. ROYAL PRIMA MEDAN
}

\author{
Tiarnida Nababan ${ }^{1}$, Karmila Br Kaban ${ }^{2}$, Eva Latifah Nurhayati ${ }^{3}$, \\ Rahmad Hidayat Nasution ${ }^{4}$ \\ ${ }^{1,2,3,4}$ Fakultas Keperawatan dan Kebidanan \\ Universitas Prima Indonesia, Medan, Indonesia \\ Email: tiarnidan@yahoo.com
}

\begin{abstract}
Diabetes melitus is the result of the interaction of genetic factors and environmental exposure. Genetic factors will determine the individuals susceptible to diabetes and over time causes serious damage many systems of the body, especially the nerves and blood vessels. Diabetes is caused by diet or nutrition, unhealthy habits, stress, and lack of physical activity. This study aims to determine the relationship of stress levels to elevated blood sugar levels in patients with type II DM in Royal Prima Hospytal Medan. The research design used is correlation (Correlation Study) with Cross Sectional approach. The sample of this research is patient of DM type II disease with sample number 67 respondent using chi-square statistic test. Based on chi-square statistic test can be obtained result of 0,04 that is <0,05 means smaller than value $\alpha=0,05$. Thus drawn conclusion there is a relationship of stress level to increase blood sugar levels in DM tipe II patients in Royal Prima Hospytal Medan. From the results of the study concluded that there is a relationship level of stress to elevated blood sugar levels in patients DM tipe II. Suggested to Royal Prima Hospytal Medan recommends that patients keep control of stress on natural problems and diseases in order not to lead to other forms of disease.
\end{abstract}

Keywords: stress level, increased blood sugar levels, diabetes melitus

PENDAHULUAN

Menurut WHO (World Health Organization) diabetes adalah penyakit kronis disaat pankreas tidak menghasilkan cukup insulin atau tubuh tidak dapat secara efektif menggunakan insulin yang dihasilkannya. Diabetes yang tidak terkontrol dan seiring berjalannya waktu menyebabkan kerusakan serius pada banyak sistem tubuh, terutama saraf dan pembuluh darah. Pada tahun 2014, 8,5\% orang dewasa berusia 18 tahun ke atas menderita diabetes. Pada tahun 2015, diabetes adalah penyebab langsung 1,6 juta kematian dan pada tahun 2012 glukosa darah tinggi adalah penyebab 2,2 juta kematian lainnya (World Health Organization [WHO], 2016)

Menurut Kemenkes RI (2013) penyakit diabetes disebabkan oleh pola makan atau nutrisi, kebiasaan tidak sehat, stres, dan kurangnya aktivitas fisik. Prevalensi diabetes didapatkan sebanyak 21\% pada tahun 2013 di Indonesia. Angka tersebut lebih tinggi dibanding prevalensi tahun 2007 (1,1\%).

Sebanyak 31 provinsi $(93,9 \%)$ 
menunjukkan kenaikan prevalensi DM yang cukup tinggi. Prevalensi tertinggi diabetes pada umur $\geq 15$ tahun, menurut diagnosis dokter atau gejala adalah di Provinsi Sulawesi Tengah (3,7\%), kemudian diikuti provinsi Sulawesi Utara $(3,6 \%)$ dan Sulawesi Selatan $(3,4 \%)$, sedangkan Provinsi Jawa Tengah menempati urutan ke-21 mengalami peningkatan prevalensi sebesar $1,2 \%$ pada tahun 2007 menjadi 1,9\% pada tahun 2013.

Menurut Riskesdas (2018), jika dibandingkan dengan tahun 2013, prevalensi DM berdasarkan diagnosis dokter pada penduduk umur $\geq 15$ tahun dan meningkat menjadi $2 \%$ pada tahun 2018. Prevalensi DM berdasarkan diagnosis dokter dan usia $\geq 15$ tahun yang terendah terdapat di Provinsi NTT, yaitu sebesar $0,9 \%$, sedangkan prevalensi DM tertinggi di Provinsi DKI Jakarta sebesar 3,4\%, dan di Sumatera Utara $2 \%$.

Diabetes melitus merupakan hasil interaksi faktor genetik dan keterpaparan lingkungan. Menurut penelitian Imelda (2019) mendapatkan faktor yang paling mempengaruhi terjadinya diabetes melius yaitu faktor kurangnya aktivitas dan juga adanya riwayat keturunan dan pola makan yang tidak sehat.

Berdasarkan hasil penelitian Izzati dan Nirmala (2015) didapatkan 62,5\% mengalami stres sedang dan 56,3\% tidak mengalami peningkatan kadar gula darah dan. Hasil analisa bivariat ada hubungan tingkat stres dengan kadar gula darah pasien diabetes melitus di wilayah kerja Puskesmas Perkotaan Rasimah Ahmad Bukittinggi 2015. Hasil penelitian Irfan dan Wibowo (2015) hubungan tingkat stres dengan kadar gula darah pada penderita DM di Puskesmas Peterongan Jombangterdapat ada hubungan antara tingkat stres dengan kadar gula darah pada penderita DM di Puskesmas Peterongan Jombang.

Menurut Lathifah (2017) berdasarkan analisis didapatkan bahwa ada hubungan antara durasi penyakit dengan keluhan subyektif pada penderita DM Tipe 2 dan kadar gula darah dengan keluhan subyektif pada penderita DM tipe 2 .

Menurut Chaidir, Wahyuni, dan Furkhani (2017) Pasien diabetes melitus rentan mengalami komplikasi yang disebabkan oleh peningkatan kadar gula darah. Peningkatan kadar gula darah dapat dicegah dengan melakukan self care terdiri dari pengaturan diet, olah raga, terapi obat, perawatan kaki, dan pemantauan gula darah.

Menurut survei awal yang dilakukan di RSU. Royal Prima Medan terdapat 404 orang yang menderita penyakit diabetes melitus. Kasus yang selalu meningkat dan menjadi perhatian masyarakat untuk memberikan dukungan kepada pasien dan keluarga 
yang menderita penyakit diabetes melitus tersebut peneliti tertarik mengangkat kasus ini. Kecenderungan peningkatan prevalensi akan dapat mempengaruhi tingkat stres pada pasien. Tujuan penelitian untuk mengetahui hubungan hubungan tingkat stres terhadap peningkatan kadar gula darah pada pasien DM tipe II di RSU Royal Prima Medan.

\section{METODE}

Desain penelitian ini bersifat korelasi (Correlation Study) dengan pendekatan Cross Sectional yang dilakukan untuk menjelaskan hubungan tingkat stres terhadap peningkatan kadar gula darah pada pasien diabetes melitus tipe II di RSU. Royal Prima Medan. Waktu penelitian pada bulan Februari 2018.

Populasi dalam penelitian ini sebanyak 404 pasien DM. Teknik pengambilan sampel dengan teknik purposive sampling, maka sampel berjumlah 67 orang. Metode pengambilan data menggunakan kuesioner dan alat tes kadar gula darah.

Analisa data meliputi analisa univariat dan bivariat. Analisa univariat dalam bentuk tabel distribusi frekuensi. Analisa bivariat untuk mengetahui hubungan (korelasi) antara variabel bebas (independent variable) dengan terikat (dependen variable) dengan uji Chi-Square.

\section{HASIL DAN PEMBAHASAN}

Hasil

\section{Analisa Univariat}

Analisa univariat menjelaskan tenntang hasil penelitian berdasarkan frekuensi tingkat stress pada pasien DM tipe II dan kadar gula darah pada pasien DM tipe II.

Tabel 1. Distribusi Frekuensi Tingkat Stres Pada Pasien DM Tipe II

\begin{tabular}{clrc}
\hline No & $\begin{array}{c}\text { Tingkat } \\
\text { Stres }\end{array}$ & $\begin{array}{c}\text { Jumlah } \\
(\mathbf{n})\end{array}$ & \multicolumn{1}{c}{$\%$} \\
\hline 1 & Normal & 41 & 61,2 \\
2 & Stres ringan & 18 & 26,9 \\
3 & Stres berat & 8 & 11,9 \\
\hline & Total & 67 & 100 \\
\hline
\end{tabular}

Berdasarkan tabel tingkat stres pada pasien DM tipe II di atas, mayoritas yang memiliki tingkat stres normal sebanyak 41 responden $(61,2 \%)$, tingkat stres ringan 18 responden $(26,9 \%)$, dan tingkat stres dengan berat sebanyak 8 responden $(11,9 \%)$.

\section{Tabel 2. Distribusi Frekuensi Kadar Gula Darah Pada Pasien DM Tipe II}

\begin{tabular}{clcc}
\hline No & $\begin{array}{l}\text { Kadar Gula } \\
\text { Darah }\end{array}$ & $\begin{array}{c}\text { Jumlah } \\
\text { (n) }\end{array}$ & $\%$ \\
\hline 1 & Tidak & 32 & 47,8 \\
& Normal & 35 & 52,2 \\
2 & Normal & 35 & 100 \\
\hline & Total & 67 &
\end{tabular}

Berdasarkan tabel kadar gula darah pada pasien di atas, mayoritas yang memiliki kadar gula darah yang tidak normal sebanyak 32 responden $(47,8 \%)$, dan kadar gula darah normal sebanyak 35 responden $(52,2 \%)$. 


\section{Analisa Bivariat}

Tabel 3. Hubungan Tingkat Stres Dengan Peningkatan Kadar Gula Darah Pada Pasien DM Tipe II

\begin{tabular}{|c|c|c|c|c|c|c|c|}
\hline \multirow{3}{*}{ Tingkat Stres } & \multicolumn{4}{|c|}{ Kadar Gula } & \multirow{2}{*}{\multicolumn{2}{|c|}{ Jumlah }} & \multirow{2}{*}{ p Value } \\
\hline & \multicolumn{2}{|c|}{ Normal } & \multicolumn{2}{|c|}{ Tidak Normal } & & & \\
\hline & $\mathrm{n}$ & $\%$ & $\mathrm{n}$ & $\%$ & $\mathrm{n}$ & $\%$ & \multirow{4}{*}{0,04} \\
\hline Normal & 26 & 38,8 & 15 & 24,4 & 41 & 61,2 & \\
\hline Stres Ringan & 5 & 7,5 & 13 & 19,4 & 18 & 26,9 & \\
\hline Stres Berat & 1 & 1,5 & 7 & 10,4 & 8 & 11,9 & \\
\hline Jumlah & 32 & 47,8 & 35 & 52,2 & 67 & 100 & \\
\hline
\end{tabular}

Berdasarkan tabel tabulasi silang antara hubungan tingkat stres dengan peningkatan kadar gula darah pada pasien DM tipe II di atas, diketahui bahwa dari 67 responden (100\%) yang memiliki tingkat stres normal dengan KGD normal sebanyak 26 responden $(38,8 \%)$, dan responden yang mengalami tingkat stres normal dengan kategori KGD tidak normal sebanyak 15 responden $(24,4 \%)$. Tingkat stres ringan dengan KGD normal sebanyak 5 responden $(7,5 \%)$ dan KGD yang tidak normal sebanyak 13 responden $(19,4 \%)$.

Dan kategori tingkat stres berat dengan KGD sebanyak 1 responden (1,5\%) dan responden yang KGD nya tidak normal sebanyak 7 responden $(10,4 \%)$.

Setelah dilakukan uji statistik dengan menggunakan uji chi-square maka dapat diperoleh hasil $<0,05$ yaitu 0,04 berarti lebih kecil dari $\mathrm{p}$ value $\alpha=0,05$. Dengan demikian ditarik kesimpulan ada hubungan tingkat stres dengan peningkatan kadar gula darah pada pasien DM tipe II RSU. Royal Prima Medan.

\section{Pembahasan}

Hasil penelitian tentang tingkat stres responden di RSU Royal Prima Medan didapat bahwa mayoritas yang memiliki tingkat stres normal sebanyak 41 orang $(61,2 \%)$. Tingkat stres ringan sebanyak 18 (26,9\%). Tingkat stres berat sebanyak 8 (11,9\%). Hal ini menunjukkan bahwa responden memiliki stres yang berbeda-beda dan memiliki cara mengendalikan kadar gula darahnya dan menerima penyakitnya. Sedangkan penelitian Anggeria dan Siregar, (2019) mendapatkan bahwa penerimaan diri pasien Diabetes Melitus tipe II, mayoritas penerimaan diri baik. Hal ini dapat terjadi karena sebagian pasien diabetes sudah mampu menerima keadaan dirinya, dan dapat memberikan diabetes ruang yang diperlukan dalam hidupnya.

\section{Tingkat Stres Pada Pasien DM Tipe II}

Berdasarkan tingkat stres pasien DM tipe II di RSU Royal Prima Medan didapatkan dari 67 responden tingkat stres yang kategori normal 41 responden $67,2 \%$, kategori tingkat stres ringan 
terdapat 18 responden $(26,9 \%)$, dan kategori stres berat sebanyak 8 responden $(11,9 \%)$. Penelitian Derek, Rottie dan Kallo (2017) terdapat hubungan tingkat stres dengan kadar gula darah pada pasien diabetes melitus tipe II di Rumah Sakit Pancaran Kasih GMIM Manado. Penelitian Irfan dan Wibowo (2015) mendapatkan ada hubungan antara tingkat stres pada penderita DM dengan kategori sedang.

Menurut asumsi peneliti stres sangat berpengaruh terhadap peningkatan kadar gula darah pada penderita penyakit DM. Seseorang yang mengalami stres akan mengalami gangguan pada sistem endokrin yaitu kadar gula darah yang meninggi dan bila berkelanjutan dapat mengakibatkan penyakit diabetes melitus, salah satu upaya mencegah terjadinya stres dengan menyibukkan kegiatan yang membuat hati senang, olahraga, meditasi, berfikiran positif, refreshing (Hawari, 2013).

\section{Kadar Gula Darah pada Pasien DM Tipe II}

Berdasarkan kadar gula darah pada pasien DM tipe II bahwa dari 67 responden diperoleh hasil penelitian di RSU Royal Prima Medan mendapatkan kadar gula darah tidak normal sebanyak 32 responden $(47,8 \%)$, yang memiliki kadar gula darah normal sebanyak 35 responden $(52,2 \%)$. Hal ini menunjukkan adanya kadar gula darah yang berbeda-beda pada setiap orang.
Diabetes melitus dapat disebabkan oleh beberapa faktor, dan terjadi pada pasien yang tidak menjaga pola makan dan menghindari faktor resiko yang lain.

Hasil penelitian Amir, Wungouw, dan Pangemanan (2015) menunjukkan bahwa pasien DM tipe II di Puskesmas Bahu Kota Manado menunjukkan sebagian besar memiliki rerata kadar glukosa darah sewaktu yang tinggi dengan kendali glukosa darah yang buruk. Hasil penelitian Ramadhan, Marissa, Fitria, dan Wilya (2018) menunjukkan $81,2 \%$ nilai $\mathrm{HbA} 1 \mathrm{c} \geq 7 \%$, $80 \%$ nilai GDP $\geq 100 \mathrm{mg} / \mathrm{dl}, 85,9 \%$ nilai GD 2 jam PP $\geq 140 \mathrm{mg} / \mathrm{dl}, \quad 58,8 \%$ dan tekanan darah $\geq 130$. Penelitian ini menunjukkan hasil pengendalian DM yang baik, dan menggambarkan capaian pengendalian DM masih di bawah nilai cut off yang ditetapkan Perkumpulan Endokrinologi Indonesia (PERKENI).

Hasil temuan penelitian ini bahwa responden yang tidak mengalami peningkatan kadar gula darah disebabkan responden patuh menjalani diet diabetes sesuai aturan makan bagi pasien diabetes, sering konsultasi dengan dokter, melakukan aktivitas fisik, mengurangi atau menghindari stres serta minum obat diabetes.

\section{Hubungan Tingkat Stres Dengan Peningkatan Kadar Gula Darah Pada Pasien DM Tipe II}

Berdasarkan hubungan tingkat stres terhadap peningkatan kadar gula darah 
pada pasien DM tipe II di RSU Royal

Prima Medan didapati hasil uji statistik dengan menggunakan uji chi-square maka dapat diperoleh hasih $<0,05$ yaitu 0,04, maka kesimpulan ada hubungan tingkat stres dengan peningkatan kadar gula darah pada pasien DM tipe II.

Penderita DM tipe 2 memerlukan penatalaksanaan DM secara baik dan teratur untuk menjaga agar kadar gula darah tetap terkendali. Kadar gula darah yang tidak terkendali dapat meningkatkan komplikasi akibat DM tipe 2, dan menyebabkan kematian. Berdasarkan penelitian Fahmiyah dan Latra (2016) menyatakan faktor atau variabel yang signifikan memengaruhi kadar GDP adalah kadar HDL, LDL, dan Trigliserida dengan ketepatan model dalam mengklasifikasikan sebesar $70 \%$.

Faktor risiko DM tipe-2 terutama adalah obesitas dan riwayat keluarga dengan DM tipe-2. Faktor risiko lainnya adalah berat badan lahir rendah (kecil masa kehamilan) dan status gizi buruk (IMT rendah) pada usia 2 tahun. Gambaran klinis anak dan remaja dengan DM tipe-2 dapat bervariasi dari hiperglikemi tanpa gejala yang ditemukan pada skrining atau pemeriksaan fisik rutin sampai koma ketoasidosis (25\% pasien) atau status hiperosmolar hiperglikemik yang dapat meningkatkan risiko mortalitas (IDAI, 2015).
Menurut asumsi peneliti, berdasarkan kategori KGD normal adalah responden yang rajin pantau KGD, dan rutin minum obat KGD. Sedangkan responden yang mengalami stres berat dengan kategori KGD tidak normal adalah responden yang tidak dapat mengatasi masalah stresnya dan KGD di abaikan dengan tidak rutin minum obat penurun KGD.

Seseorang yang divonis diabetes dapat mengalami stres, yang kemudian menyulitkan kontrol gula darahnya, Demikian pula dengan penyandang diabetes yang sehari-hari mengalami stres misalnya akibat pekerjaan, lingkungan sosial, atau tekanan dalam keluarga pengontrolan gula darahnya cenderung lebih buruk. Keadaan dimana stres sulit dihindari akibat gula darah yang tidak normal dapat membuat seseorang menyerah dan akhirnya mengabaikan pengelolaan diabetes yang dimilikinya. Hal ini tentu berbahaya, mengingat diabetes yang tidak dikelola dengan baik dapat berujung pada komplikasi yang berbahaya.

\section{KESIMPULAN DAN SARAN}

\section{Kesimpulan}

Hasil analisa univariat didapatkan bahwa dari 67 responden diperoleh hasil tingkat stres yang kategori normal sebanyak 41 responden, kategori tingkat stres ringan terdapat 18 responden, dan 
kategori stres berat sebanyak 8 responden.

Berdasarkan kadar gula darah pada pasiem DM tipe II diperoleh hasil yang memiliki kadar gula darah tidak normal sebanyak 32 responden, yang memiliki kadar gula darah normal sebanyak 35 responden. Prevalensi penderita DM tipe II masih tinggi dan kondisi ini mempengaruhi tingkat stres pada pasien.

Berdasarkan hubungan tingkat stres terhadap peningkatan kadar gula darah pada pasien DM tipe II di RSU Royal Prima Medan didapati hasil uji statistik dengan menggunakan uji chi-square maka dapat diperoleh hasil $p$ value 0,04

\section{Saran}

Peneliti selanjutnya disarankan mengkaji responden untuk memahami tingkat stres yang dialaminya. Peneliti selanjutnya juga diharapkan dapat menemukan upaya pencegahan diabetes melitus terhadap penurunan tingkat stress pada pasien.

\section{DAFTAR PUSTAKA}

Amir, S. M. J., Wungouw, H., \& Pangemanan, D. (2015). Kadar glukosa darah sewaktu pada pasien diabetes melitus tipe 2 di Puskesmas Bahu Kota Manado. Jurnal EBiomedik.

https://doi.org/10.35790/ebm.3.1.201 5.6505

Anggeria, E., \& Siregar, P. S. (2019). Efektivitas perawatan ulkus diabetikum terhadap penerimaan diri pasien diabetes melitus tipe II. Jurnal Jumantik, 4(2), 178-187.
Chaidir, R., Wahyuni, A. S., \& Furkhani, D. W. (2017). Hubungan self care dengan kualitas hidup pasien diabetes melitus. Jurnal Endurance. https://doi.org/10.22216/jen.v2i2.135 7

Derek, M., Rottie, J., \& Kallo, V. (2017). Hubungan tingkat stres dengan kadar gula darah pada pasien diabetes melitus tipe II di Rumah sakit pancaran kasih GMIM Manado. JURNAL KEPERAWATAN.

Fahmiyah, I., \& Latra, I. (2016). Faktor yang memengaruhi kadar gula darah puasa pasien diabetes mellitus tipe 2 di Poli Diabetes RSUD Dr. Soetomo Surabaya Menggunakan Regresi Probit Biner. Jurnal Sains Dan Seni ITS.

https://doi.org/10.12962/j23373520.v $5 \mathrm{i} 2.17384$

Hawari, D. (2013). Stres, cemas dan depresi. In Jakarta: EGC.

IDAI. (2015). Konsensus nasional pengelolaan diabetes melitus tipe-2 pada anak dan remaja. Retrieved from

http://spesialis1.ika.fk.unair.ac.id/wp

content/uploads/2017/03/KonsensusNasional-Pengelolaan-DIabetesNasional-Type-II.pdf

Irfan, M., \& Wibowo, H. (2015). Hubungan tingkat stres dengan kadar gula darah pada penderita diabetes mellitus di Puskesmas Peterongan Kabupaten Jombang. Jurnal Keperawatan STIKES Pemkan Jombang. https://doi.org/10.1111/j.14209101.2006.01088.x

Izzati, W., \& . N. (2015). Hubungan tingkat stres dengan peningkatan kadar gula darah pada pasien diabetes mellitus di wilayah kerja Puskesmas Perkotaan Rasimah Ahmad Bukittinggi Tahun 2015. 'Afiyah.

Kemenkes RI. (2013). Riskesdas 2013. RISKESDAS

2013. https://doi.org/10.1517/13543784.7.5 .803 
Lathifah, N. L. (2017). Hubungan durasi penyakit dan kadar gula darah dengan keluhan subyektif penderita diabetes melitus. Jurnal Berkala Epidemiologi.

https://doi.org/10.20473/jbe.v5i2.201 7.231-239

Ramadhan, N., Marissa, N., Fitria, E., \& Wilya, V. (2018). Pengendalian diabetes melitus tipe 2 pada pasien di Puskesmas Jayabaru Kota Banda Aceh. Media Penelitian dan Pengembangan Kesehatan. https://doi.org/10.22435/mpk.v28i4.6 3

RISKESDAS. (2018). Hasil Utama Riskesdas tentang prevalensi diabetes mellitus di Indonesia 2018. Hasil Utama Riskesdas Tentang Prevalensi Diabetes Melitus Di Indonesia 2018.

World Health Organization. (2016). Diabetes Country Profiles 2016 Indonesia.

Who. https://doi.org/10.1111/j.1467-

825X.2011.03931.x 